\title{
Bisphenol, Diethylstilbestrol, Polycarbonate and the Thermomechanical Properties of Epoxy-Silica Nanostructured Composites
}

\author{
Francisco Torrens ${ }^{1, *}$ and Gloria Castellano \\ ${ }^{1}$ Institut Universitari de Ciència Molecular, Universitat de València, Edifici d'Instituts de Paterna, P. O. Box \\ 22085, 46071 València, Spain \\ ${ }^{2}$ Facultad de Veterinaria y Ciencias Experimentales, Universidad Católica de Valencia San Vicente Mártir, \\ Guillem de Castro-94, E-46001 València, Spain
}

\begin{abstract}
The report has a double character: it deals with the synthesis and preparation of a series of polymers based on bisphenol-A (BPA) monomer; a series of physical and thermomechanical properties are examined for one type (diglycidyl ether of BPA, DGEBA with nanosilica) of the prepared materials. The reactions involved in diepoxy curing with a diamine, functional group modelling for cross-linked polymers, formation of a polymer DGEBA, BPA polyaddition to DGEBA forming a polyether, DGEBA curing with Jeffamine and cross-linking to form a resin are analyzed. Nanocomposites of silica, coated with cross-linked epoxy-amine, are synthesized and examined by ${ }^{29} \mathrm{Si}$-magic-anglespinning nuclear magnetic resonance and Fourier-transform infrared spectroscopies, thermogravimetric and dynamic mechanical analyses, differential scanning calorimetry and scanning electron microscopy. Epoxy matrix is filled with nanosilica to design materials with defined properties. A low weight percentage of filler results in matrix improvement.
\end{abstract}

Keywords: Polycarbonate, polymer, nanocomposite, nanosphere, nanosilica, amine, nanostructure, nanomaterial.

\section{INTRODUCTION}

Bisphenol-A (BPA, cf. Figure 1) level detected in food and drinks received media attention. It is used to manufacture recipients types: (1) reusable rigid ones manufactured in polycarbonate (PC) used in water bottles and (2) cans with a lacquer coating with epoxy base. Small BPA amounts pass to foods and drinks, especially with temperature. It is important in industry, e.g., PC, epoxy resin and polyacrylate syntheses, manufacturing baby bottles and coating layers for food packings. It results a health risk although proof in people is not compelling. It presents oestrogenic activity and acts as a cell epigenetic modifier [1]. Induced changes are inherited and a model is based on structurally similar diethylstilbestrol (DES). Both are biphenols synthesized from the same derivatives [2]. The BPA is a suspected endocrine disruptor. Some dental materials are based on BPA derivatives.

The DES was used as an oestrogen substitute in pregnant women to prevent miscarriage. However, 2030 years later DES babies developed a risk for vaginal neoplasia [3,4]. Mother DES exposure affects offspring inheritance increasing cancer risk, which worries because BPA alike action is possible. Pregnant women and young children exposure to BPA increases risk of

*Address correspondence to this author at the Institut Universitari de Ciència Molecular, Universitat de València, Edifici d'Instituts de Paterna, P. O. Box 22085, 46071 València, Spain; Tel: +34-963-544-431; Fax: +34-963-543-274; E-mail: francisco.torrens@uv.es tumours down line. The endocrine system is regulated so that the mother, foetus or young child presents not much wrong hormones signalling at incorrect time. Oestrogens should not be during development and infancy. They cause changes, which is a risk factor: BPA accumulation danger and combining with endocrine disruptors. However, DES and BPA are structurally different from oestrogens (17 $\beta$-oestradiol, cf. Figure 2) and carry another risks. Parallels do the principle of caution to ask for alternatives [5-9]. It was reported kinetic model of BPA curing with $m$-phenylene diamine, which incorporates $n$-order and autocatalytic mechanisms [10-12]. Benzoxazines were reviewed [13] and prepared from BPA [14]. Polymer diglycidyl ether of BPA (DGEBA), cross-linked with a diamine, results a commercially important epoxy resin and a candidate for nanocomposites (NCs). Its dielectric spectra at glass-transition temperature were reported [15]. Nanofiller effect on NC dielectric was informed [16]. Curing agent and temperature effects on rheology of epoxy resins were analyzed [17], which modification with polystyrene (PS)- $b$-polybutadiene- $b$-poly (methy methacrylate) (PMM) improved adhesive strength and toughness [18]. Concentration of BPA was evaluated by gas chromatography-mass spectrophotometry in canned food [19]. Structure-toxicity relations regarded ECOSAR toxicity of benzene-carboxylic acids' esters [20]. Lavorgna group reported plasticizing and reinforcing features of siloxane domains in amide-cured epoxy/silica hybrids [21] and functional zein-siloxane bio-hybrids [22]. 

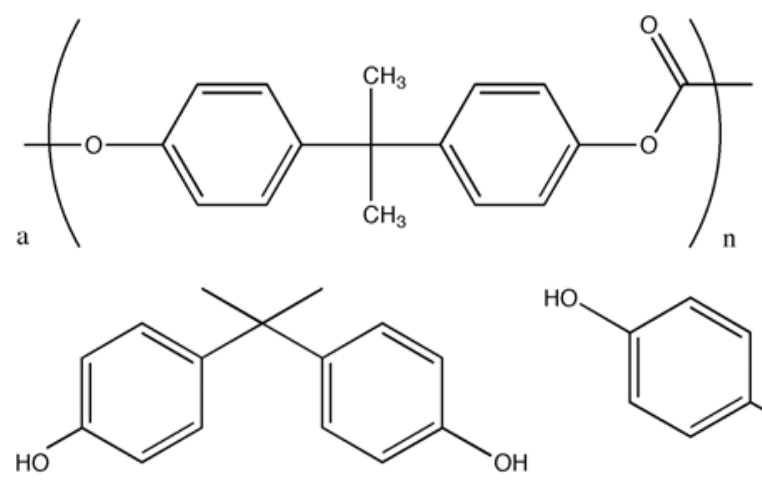

b

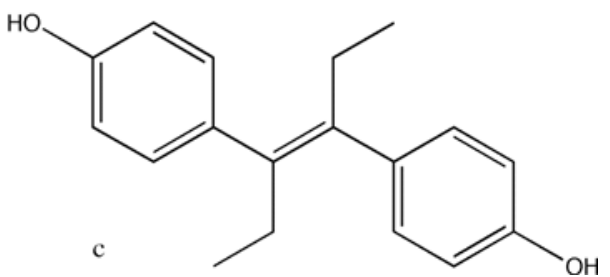

Figure 1: Structures of (a) polycarbonate (PC), (b) bisphenol-A (BPA), (c) diethylstilbestrol (DES).<smiles>C[C@]12CCC3c4ccc(O)cc4CCC3C1CC[C@@H]2O</smiles><smiles>[2H]c1cc(C(C)(C)c2cc(P)c(O)c(P)c2)cc(P)c1O</smiles><smiles>Oc1ccc(Cc2ccc(O)cc2)cc1</smiles>

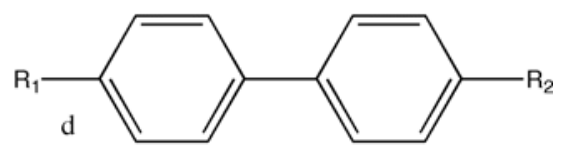

Figure 2: Structures of (a) 17 $\beta$-oestradiol; (b) BPA: BPA, $\mathrm{R}=\mathrm{H}$; tetrachlorobisphenol-A (TCBPA), $\mathrm{R}=\mathrm{Cl}$; TBBPA, $\mathrm{R}=\mathrm{Br}$; $(\mathbf{c})$ bisphenol-F (BPF); (d) biphenyl (BP): 4-hydroxybiphenyl (4-OHBP), $\mathrm{R}_{1}=\mathrm{OH}, \mathrm{R}_{2}=\mathrm{H}$; 4,4'-dihydroxybiphenyl (4,4-OHBP), $\mathrm{R}_{1}=$ $\mathrm{R}_{2}=\mathrm{OH}$.

In earlier publications, it was examined poly (styrene-co-methacrylic acid)-b-poly(4-vinylpyridine) treatment in solution, under liquid-liquid phaseseparation conditions with viscometry [23], compatibility between PS (co-)polymers in solution via hydrogen bonding [24], interaction parameters, and phase behaviour of epoxy/PS and/co-polymer PS- $b-P M M$ $[25,26]$. The phase behaviour of monomer/polymer/disc NCs was theoretical [27,28] and experimentally [29] modelled. In NCs, DGEBA was used to analyze epoxy/PS and - $b$-PMM interaction parameters, phase behaviour [30], nanosilica $\left(\mathrm{SiO}_{2}\right)$ incorporation into epoxy-amine cross-linked materials forming NCs [3133] and dynamics [34,35]. The epoxy-amine polymer is filled with nano- $\mathrm{SiO}_{2}$ to design materials with desirable properties. The present report has a double character: (1) it deals with the synthesis and preparation of a series of polymers based on BPA monomer; (2) a series of physical and thermomechanical properties are examined for one type (DGEBA with nano- $\mathrm{SiO}_{2}$ ) of the prepared materials. The novelty is to investigate epoxy-amine- $\mathrm{SiO}_{2} \mathrm{NC}$ potentials. Section 2 describes the experimental procedure. In section 3 the results are presented and discussed. Finally, section 4 summarizes our conclusion.

\section{EXPERIMENTAL PROCEDURE}

\subsection{Chemical Synthesis of Bisphenol-A}

Russian chemist A. P. Dianin (1891) synthesized BPA by acetone condensation with phenol (" $A$ " in BPA). Reaction is catalyzed by strong acid, e.g., $\mathrm{HCl}$ sulphonated PS resin. Phenol excess ensures full condensation (cf. Figure 3) [36].

The BPA is used to make plastics, which were in commercial use (1957), e.g., in polysulphone and polyether ketone synthesis, antioxidant in plasticizers, polymerization inhibitor in polyvinyl chloride, precursor to flame retardant tetrabromobisphenol-A (TBBPA, cf. Figure 4), was used as fungicide, is preferred colour developer in carbonless copy and thermal papers, and products are used in foundry castings and lining water pipes. 


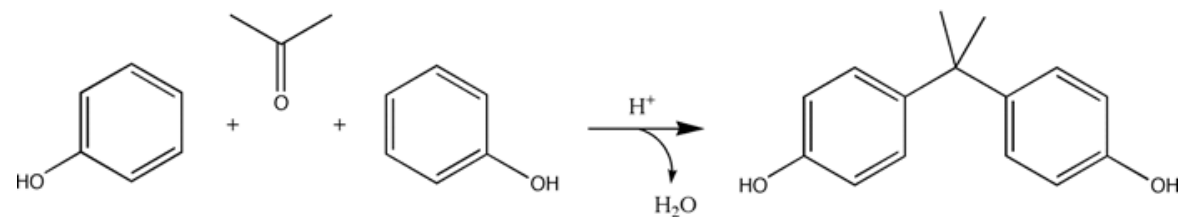

Figure 3: Chemical synthesis of bisphenol-A (BPA).

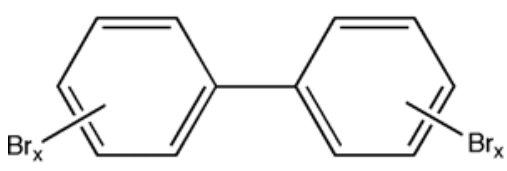<smiles>CC1CCC(Br)C(Br)CCC(Br)C(Br)CCC1C</smiles>

Figure 4: Structures of (a) polybrominated biphenyls hexabromocyclododecane (HBCD) and (d) TBBPA.

\subsection{Epoxy Resin Diglycidyl Ether of Bisphenol-A DER332}

The thermosetting matrix was obtained via epoxyamine polycondensation. The diepoxy prepolymer was commercial DER332 from Dow Chemicals (cf. Figure 5): epoxy content was $5.78 \mathrm{eq} \cdot \mathrm{kg}^{-1}$ determined by acid titration, equivalent weight $173 \mathrm{~g} \cdot \mathrm{eq}^{-1}$ (pure DGEBA, $\left.170 \mathrm{~g} \cdot \mathrm{eq}^{-1}\right)$. Because of high purity and low polymer fractions content, DER332 assures uniform performance, low viscosity and $\mathrm{Cl}$ content, and light colour. Under cure, resin provides improved elevatedtemperature properties over DER331. It is liquid at room temperature (RT) and fillers disperse into it. Its viscosity coefficient is $5 \mathrm{~Pa} \cdot \mathrm{S}$ at $25^{\circ} \mathrm{C}$. It is used in filament winding, electrical laminates, encapsulation and coating for corrosion under insulation [37]. Curing agent variety is available to cure at ambient conditions (cycloaliphatic polyamines, polyamides, amidoamines). Curing at elevated temperature improves properties (chemical resistance, glass-transition temperature). High-temperature cures and long post-cures are required for full-end properties if anhydride or catalytic curing agents are used. Applications are: adhesives, casting, tooling, NCs, photocure industrial coatings, potting and encapsulation. Epoxy-BPA resins are used as coatings inside food and beverage cans. However,<smiles>Brc1ccc(Oc2ccccc2)cc1Br</smiles><smiles>CC(C)(c1cc(F)c(O)c(Br)c1)c1cc(Br)c(O)c(Br)c1</smiles>

d

(PBBs) (b) polybrominated diphenyl ethers

(PBDEs) (c)

because of health concerns, in Japan epoxy coating was replaced by polyethylene terephthalate film. Molar mass and polydispersity of DER332 were determined in our laboratory via gel permeation chromatography (Waters), resulting: $M_{\mathrm{w}}=316 \mathrm{~g} \cdot \mathrm{mol}^{-1}, M_{\mathrm{n}}=310 \mathrm{~g} \cdot \mathrm{mol}^{-1}$ and $I=M_{\mathrm{w}} / M_{\mathrm{n}}=1.02$ (PS calibration).

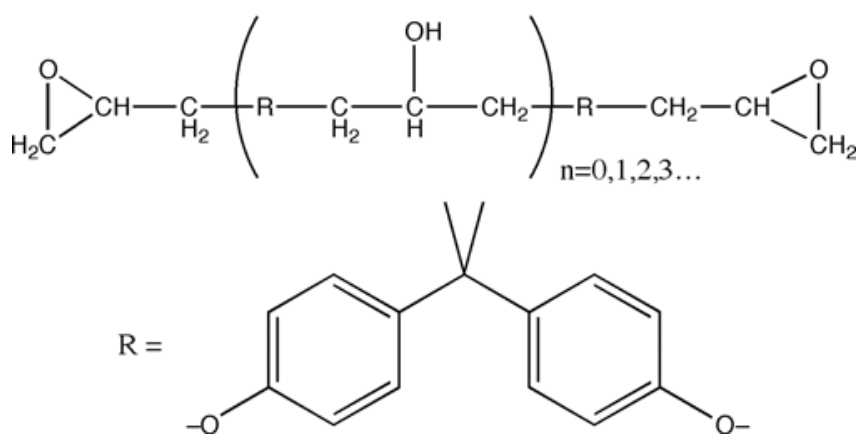

Figure 5: Diglycidyl ether of bisphenol-A (DGEBA). Molecular weight $=173 \mathrm{~g} \cdot \mathrm{eq}^{-1}$. Valency $=2$.

\subsection{Curing Agent Jeffamine ${ }^{\circledR}$ D-230 Amine}

The curing agent was primary diamine D-230 [O,O'bis(2-aminopropyl) poly(propylene glycol) from Huntsman, cf. Figure 6], which is a polyetheramine characterized by repeating oxypropylene units in the backbone. It presents long and flexible chains. Molar mass is $230 \mathrm{~g} \cdot \mathrm{mol}^{-1}$. Amine groups are located on 
secondary $C$ atoms at the end of the chain. Applications are: epoxy curing agent, it reacts with carboxylic acids to form hot-melt adhesives, reacts quickly with isocyanates and salts are formed readily for surfactant use. The benefits are: low viscosity, colour and vapour pressure, miscible with many solvents, e.g., water, it provides tough, clear, impactresistant coatings, castings and adhesives, and coatings are free of surface blush prevalent with amine curing agents.

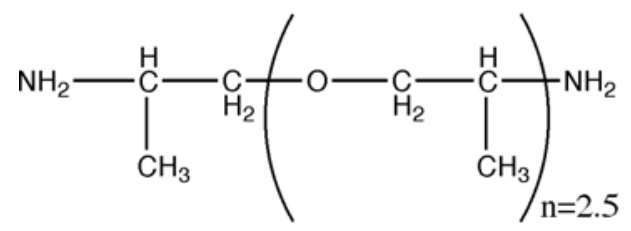

Figure 6: Curing agent (Jeffamine D-230). Molecular weight $=230 \mathrm{~g} \cdot \mathrm{eq}^{-1}$. Valency $=4$.

\subsection{Reaction of Bisphenol-A to Give Polycarbonate}

The BPA is key monomer in epoxy resin and PC (cf. Figure 7) production, which is clear and nearly shatterproof and used to make common products, e.g., baby and water bottles, sport equipment, medical and dental devices, dental fillings and sealants, eyeglass lenses, CDs and DVDs, household electronics and light valises.

\subsection{Chemical Synthesis Reaction of Diethylstil- bestrol}

The DES was synthesized by L. Golberg (1938), graduate student of Sir R. Robinson at D. Perrins Lab. at Un. of Oxford, based on formulation of W. Lawson at Courtand Inst. of Biochem. led by Sir E. C. Dodds, at Middlesex Hosp. Med. Sch. of Un. Coll. London, and synthesis was published in Nature (London) (1938). It was synthesized by English university funded by MRC, who had policy against patenting drugs discovered using public funds. Its synthesis is noted down (cf. Figure 8) [38].

\subsection{Synthesis of Benzoxazines}

Formation of benzoxazine monomers is shown (cf. Figure 9).

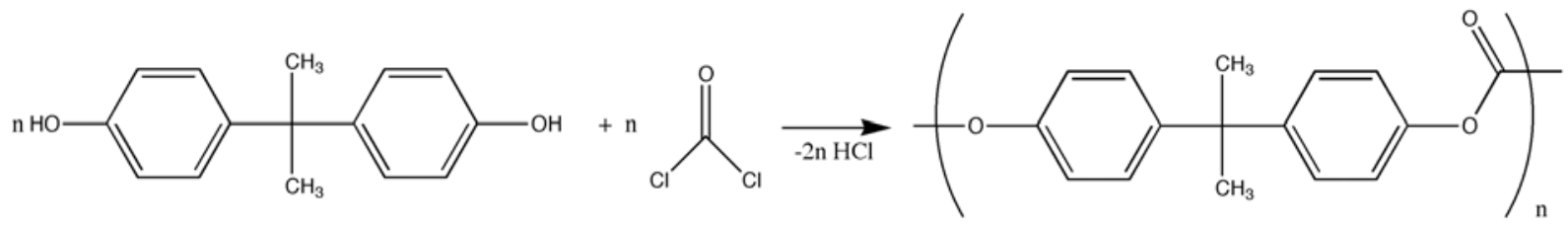

Figure 7: Reaction of bisphenol-A (BPA) to give polycarbonate (PC).

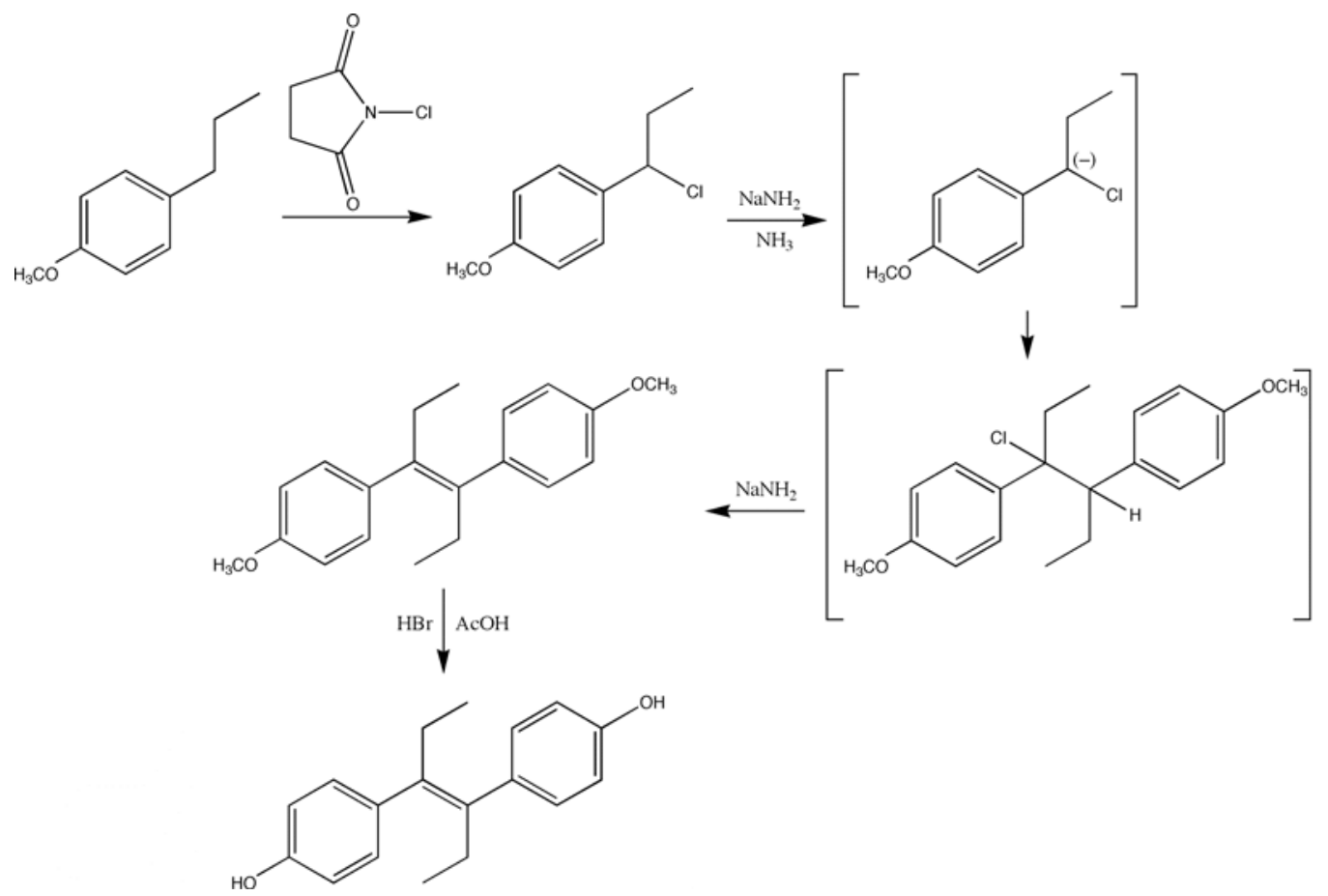

Figure 8: Chemical synthesis of diethylstilbestrol (DES). 


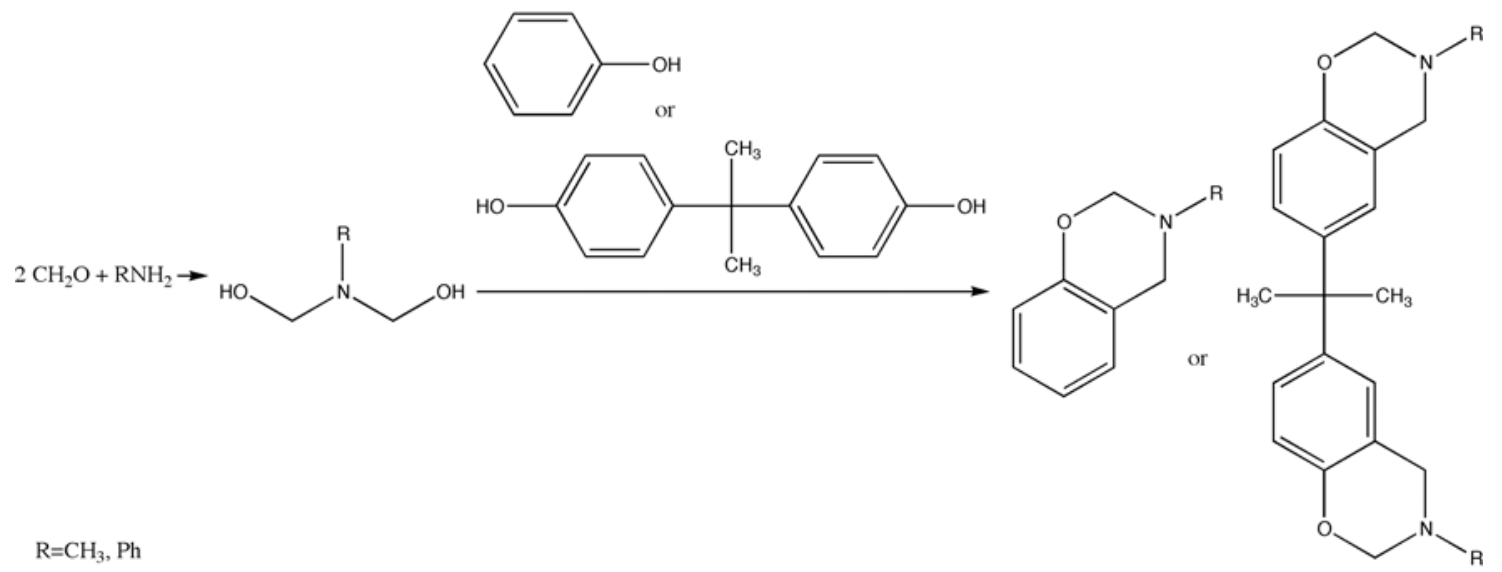

Figure 9: Chemical synthesis reaction of benzoxazines.

The proposed polymerization mechanisms are illustrated (cf. Figure 10).<smiles>CCCCCNCc1cccc(C(C)(C)C)c1O</smiles><smiles>Cc1cc(C(C)(C)c2cc(CNCC(C)(C)C)c(O)c(C(C)(C)c3ccc4c(c3)CCN(P)O4)c2)cc(CNCC(C)C)c1O</smiles>

Figure 10: Chemical synthesis reaction of polybenzoxazines by ring-opening reaction.

\subsection{Measurements}

Epoxy with and without nano- $\mathrm{SiO}_{2}$ was prepared by solution casting in amine. Dynamic mechanical properties were gauged by DMA and SDTA $861^{\mathrm{e}}$ (Mettler Toledo, $-50-150^{\circ} \mathrm{C}$, heating rate $2^{\circ} \mathrm{C} \cdot \min ^{-1}$ at $1 \mathrm{~Hz}$, deformation $1 \mathrm{~mm}$ ). Thermogravimetric analysis (TGA) was carried out for sample thermal stability under $\mathrm{N}_{2(\mathrm{~g})}\left(25-1000^{\circ} \mathrm{C}\right.$, heating rate $\left.10^{\circ} \mathrm{C} \cdot \mathrm{min}^{-1}\right)$.
Samples were recorded on scanning electron microscope (SEM). Fourier-transform infrared (FTIR) measurements were performed in a Nicolet's Nexus ${ }^{\mathrm{TM}}$ spectrometer (Thermo Electron).

\section{RESULTS AND DISCUSSION}

\subsection{Mechanism of the Epoxy and Diamine Reaction}

Mechanism occurs by autocatalytic and nonautocatalytic pathways depending on curing temperature [39-45]. Curing is characterized by gelation and vitrification: the former occurs when degree of epoxy resin cross-linking reaches critical value, which depends on functionality, stoichiometry and degree of functional-group reactivity, leading to infinite network; the latter happens when curing temperature is lesser than the maximum gelation temperature $T_{\text {gel }}$ of the completely cured system.

\subsection{Reactions Involved in Curing Diepoxy with Diamine}

For thermally stable resins, curing is necessary to obtain final cross-linked product: agents are amines and anhydrides. Epoxy networks were synthesized from DGEBA-D-230 reactions (cf. Figure 11), where epoxy groups react with primary amine $\mathrm{H}$ atoms to form secondary amines which, in turn, react with epoxy groups: in (1) and (2), epoxy reacts with amine 2:1. In high temperature or catalysts presence, epoxy group homopolymerization would occur.

\subsection{Molecular Structure in DGEBA-D-230 Resin: Start of the Cross-Linking Process}

From DER332-D-230 combination, network having low cross-link density is obtained and, at RT, it is in glassy state. Aliphatic amine reactivity is higher than 


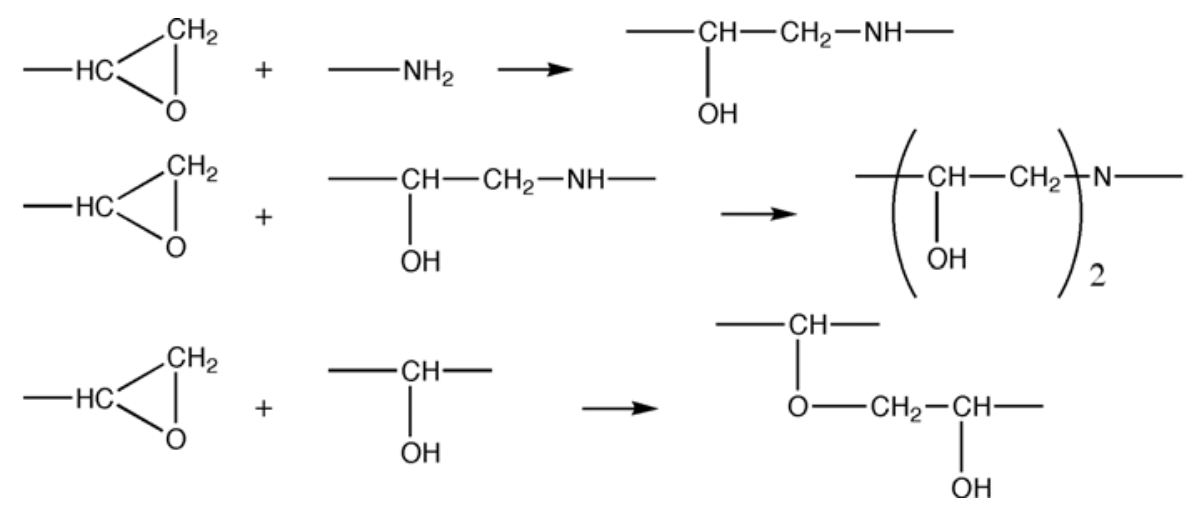

Figure 11: Three main reactions involved in the curing of a diepoxy with a diamine.

aromatic ones. However, because of long chains and $\mathrm{CH}_{3}$ close to amines, kinetics is slow. Presence of $\mathrm{O}$ atoms in chain induces polarity, which influences interactions with $\mathrm{SiO}_{2}$. Original, active and reactive functional groups for cross-linked polymers are schemed (cf. Figure 12).

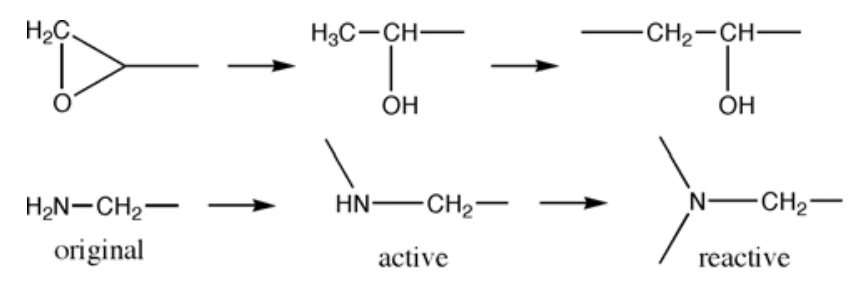

Figure 12: Modelling of functional groups for cross-linked polymers.
Synthesis of DGEBA monomer from BPA-epoxide is shown (cf. Figure 13) where $\mathrm{R}=\mathrm{Cl}$.

During synthesis, DGEBA can undergo polyaddition reaction with BPA (cf. Figure 14).

Figure 15 shows reaction of epoxide group on DGEBA monomer with amine on D-230.

Resulting product above reacts with up to three more epoxide groups, since still three $\mathrm{H}$ atoms remain between two amine groups. Cross-linking start leads to networked polymer formation (cf. Figure 16). Considerations regard: (1) $o^{-}$and $p$-structural conformation of DGEBA monomers, (2) polyether

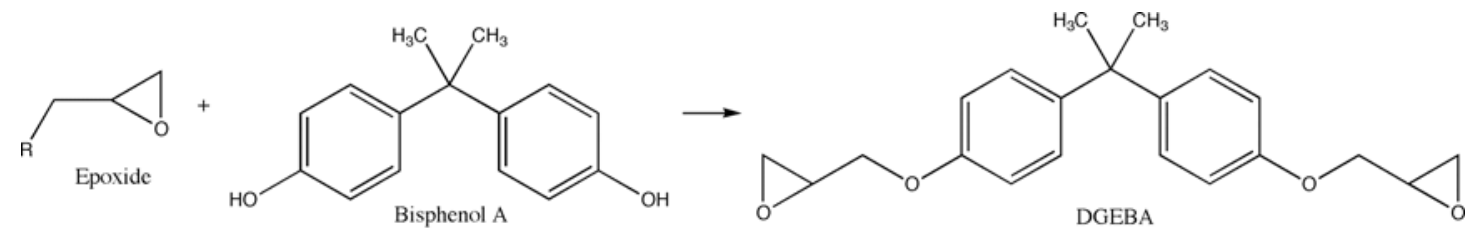

Figure 13: Formation of a DGEBA monomer in $p-p$ structural form.<smiles>CC(C)(c1ccc(O)cc1)c1ccc(OCC2CO2)cc1</smiles><smiles>CC(C)CCCOc1ccc(C(C)(C)c2ccc(OCC(O)COCC3CO3)cc2)cc1</smiles>

Figure 14: Polyaddition of bisphenol-A to DGEBA forming a polyether product. 


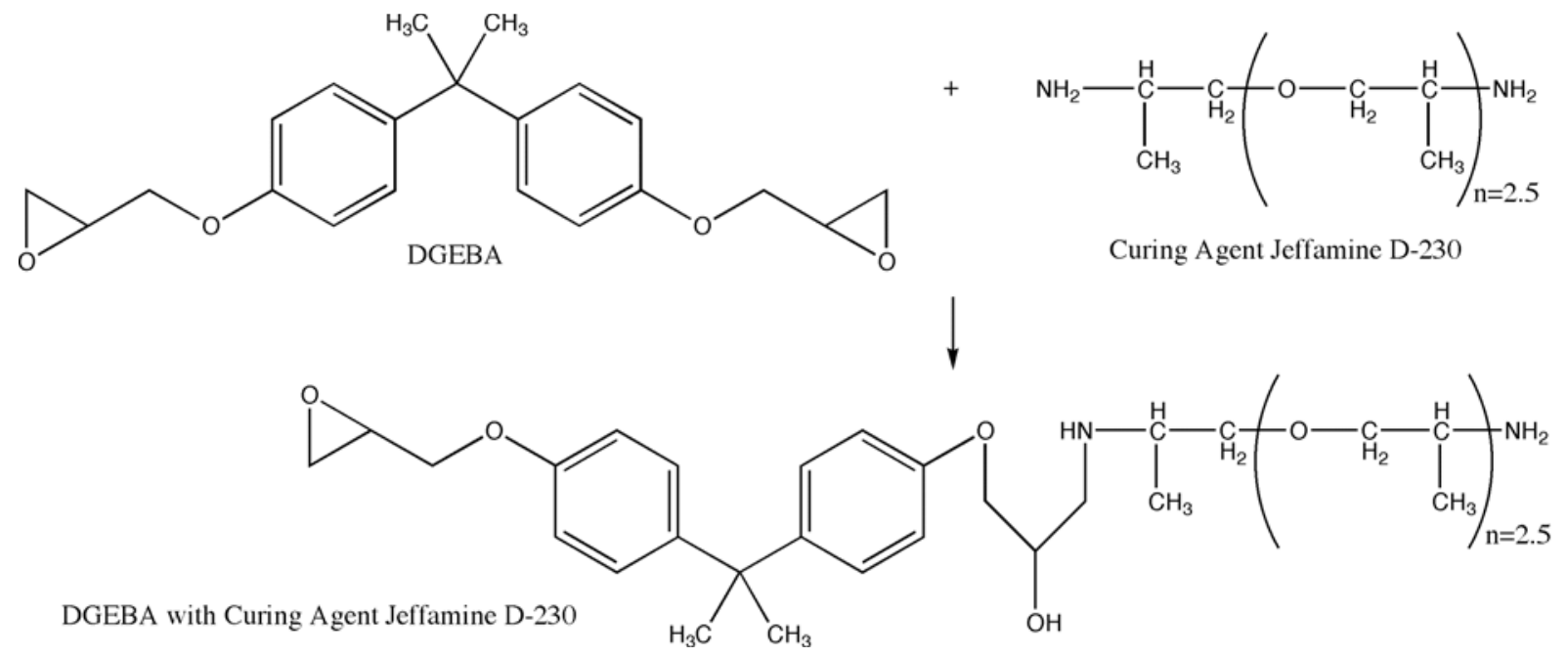

Figure 15: Reaction of DGEBA monomer with curing agent Jeffamine D-230.

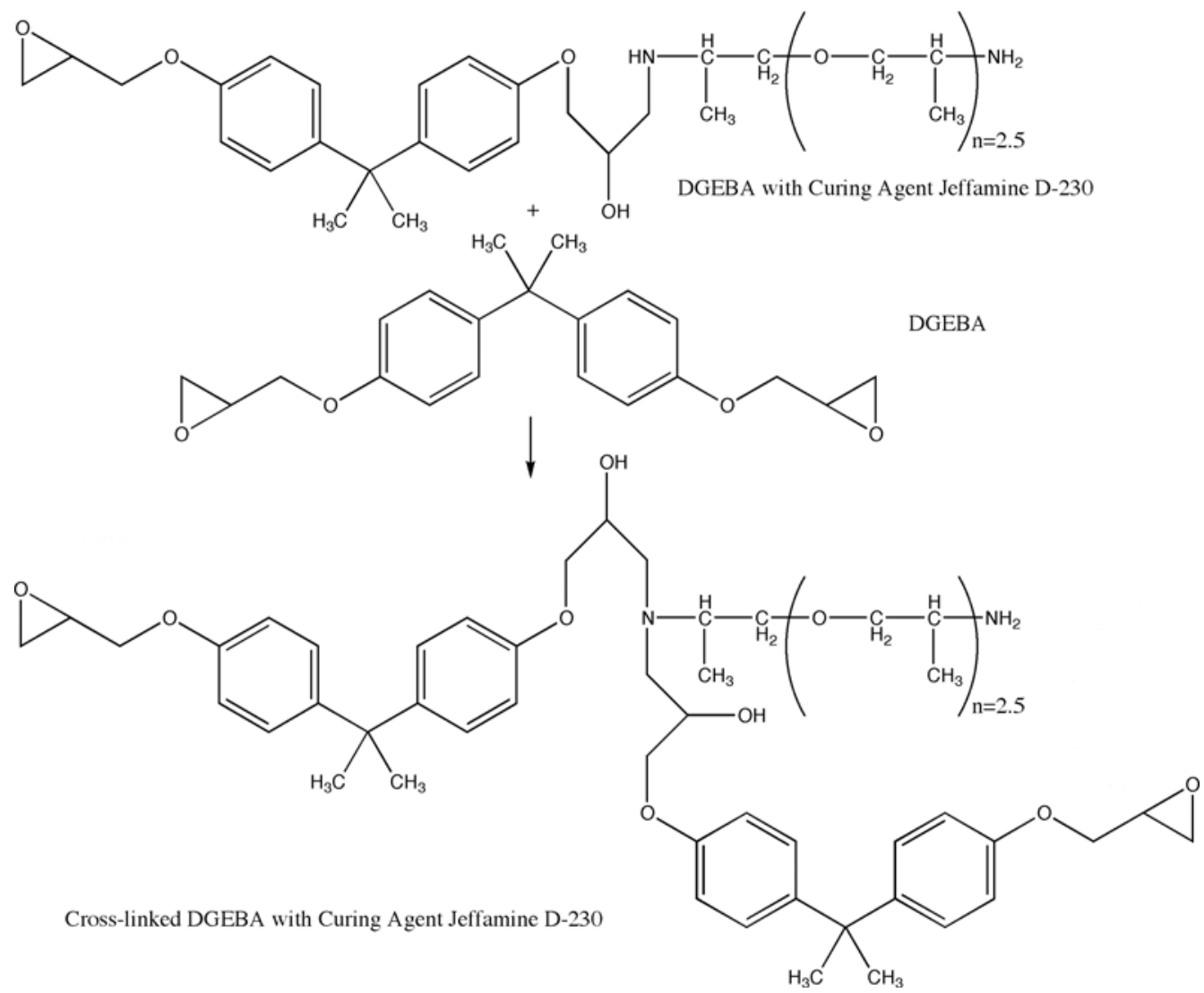

Figure 16: Start of the cross-linking process to form DGEBA/Jeffamine D-230 resin.

species fraction and (3) degree of crosslinking/molecular topology. However, for high cure degrees, (3) shows little effect on properties (density).

\subsection{Thermogravimetric Analysis, Nuclear Magnetic Resonance, SEM and FTIR}

Figure 17 shows TGA of synthetic product No. 37 (SINT-37), 2 wt.\% functional from J. Latorre (Inst. Univ.
Ciència Mater., Univ. València). At $1000^{\circ} \mathrm{C}$, epoxymodified nano-SiO 2 lost 19.3 wt.\% and unmodified nano- $\mathrm{SiO}_{2}, 14.2 \mathrm{wt} \%$, so epoxy content was estimated 5.1 wt. \%.

The ${ }^{29} \mathrm{Si}$-magic-angle-spinning nuclear magnetic resonance (NMR) spectrum of SINT-37, 2 wt.\% functional modified nano- $\mathrm{SiO}_{2}$ (cf. Figure 18) shows $\mathrm{Q}_{4 / 3 / 2}$ peaks corresponding to $\mathrm{Si}$ atom surrounded by 
four $\mathrm{O}$ atoms, three $\mathrm{O}$ atoms plus one $\mathrm{OH}$ and two $\mathrm{O}$ atoms plus two $\mathrm{OHs}$, respectively. Peaks $\mathrm{T}_{3 / 2}$ correspond to $\mathrm{Si}$ atom surrounded by three $\mathrm{O}$ atoms plus one $\mathrm{C}$ atom and two $\mathrm{O}$ atoms plus one $\mathrm{OH}$ plus one $\mathrm{C}$ atom. Both indicate epoxy groups on modifiednano- $\mathrm{SiO}_{2}$ surface and amount to $4.5 \mathrm{wt}$. \% of whole of peaks on surface in agreement with TGA.

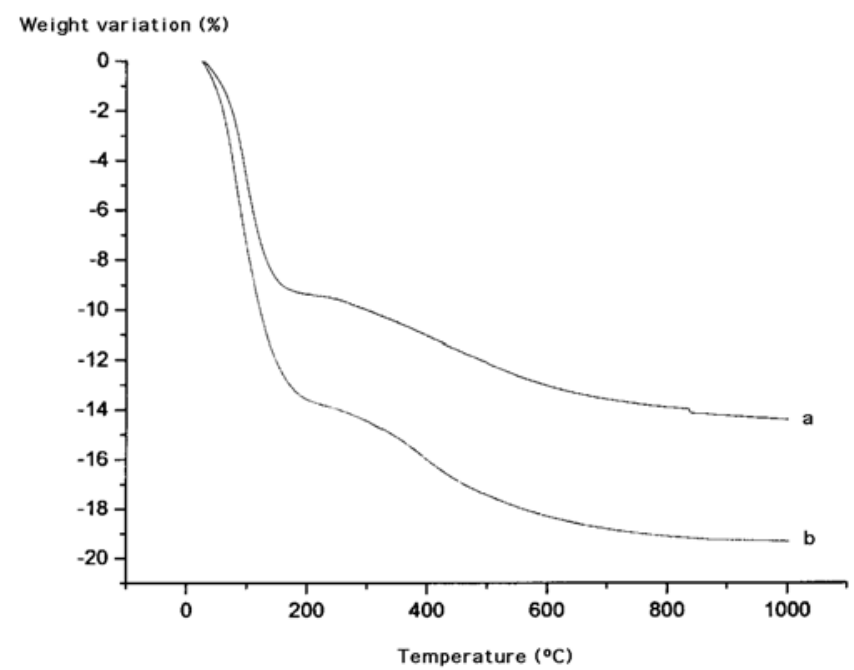

Figure 17: TGA of SINT-37, 2 wg.\% funct:: (a) unmodified and (b) epoxy-modified nano- $\mathrm{SiO}_{2}$.

The SEM of SINT-37, 2 wt.\% functional nano-SiO ${ }_{2}$ (cf. Figure 19) shows homogeneous sphere and uniform pore diameter somewhat lesser than $100 \mathrm{~nm}$.
The FTIR attenuated total reflection measurements of following samples were performed: (a) epoxy prepolymer, (b) epoxy cured with D-230, (c) epoxy plus 5 wt.\% epoxy-modified nano- $\mathrm{SiO}_{2}$ cured with $\mathrm{D}-230$ and (d) epoxy plus 50 wt.\% epoxy-modified nano- $\mathrm{SiO}_{2}$ cured with D-230. Spectra, shown as percentages of reflectance vs. wavenumbers in $400-4000 \mathrm{~cm}^{-1}$ (cf. Figure 20), indicate characteristic bands of epoxy group at 970,913 and $870 \mathrm{~cm}^{-1}$, present in all samples although more intense in (a) while (b-d) are similar. Bands at 2968, 2925 and $2870 \mathrm{~cm}^{-1}$ are attributed to C$\mathrm{H}$ vibrations present in epoxy aromatic rings, which are given by $(a-d)$ with similar intensities.

Likewise, it was carried out epoxy curing with amine-functionalized nano- $\mathrm{SiO}_{2}$, which was functionalized by reaction with 3-aminopropyltriethoxysilane (APTES, cf. Figure 21).

\subsection{Dynamic Mechanical Analysis}

At temperatures below glass transition, storage modulus in shear G' of epoxy NCs, strengthened with epoxy-amine-functionalized nano- $\mathrm{SiO}_{2}$, increased with nano- $\mathrm{SiO}_{2}$ reinforced up to $3-5$ wt.\% (cf. Figure 22).

Figure 23 shows damping factor $\tan \delta$ during glass transition in $86-92^{\circ} \mathrm{C}$. The glass-transition temperature ( $\tan \delta$ peak maximum) decays with increasing nano-

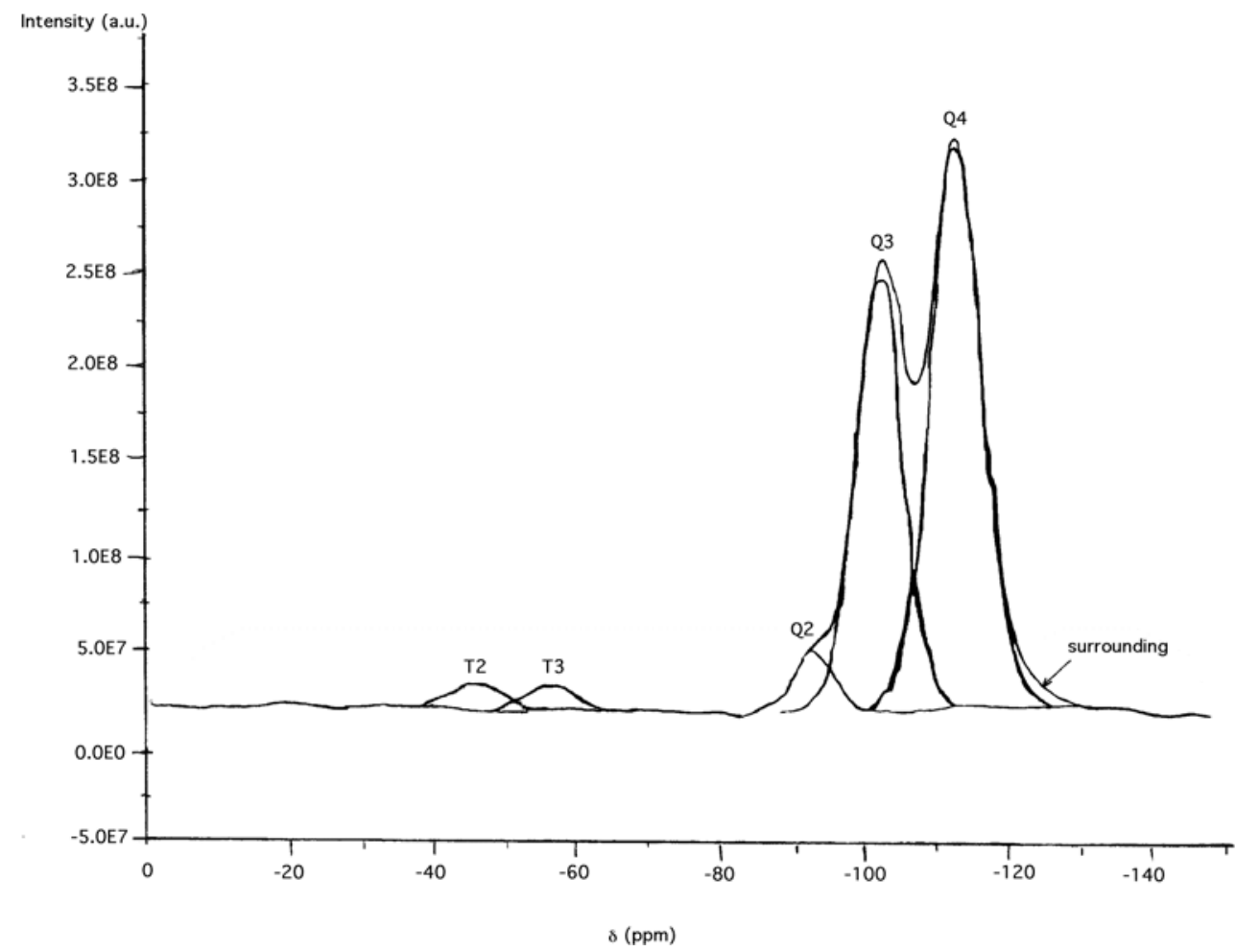

Figure 18: ${ }^{29} \mathrm{Si}-\mathrm{NMR}$ spectrum of $\mathrm{SINT}-37,2 \mathrm{wt} . \%$ functionalized (epoxy-modified nano-SiO${ }_{2}$ ). 
$\mathrm{SiO}_{2}$ content, which attributes to the higher mobility of polymer chains in NCs.

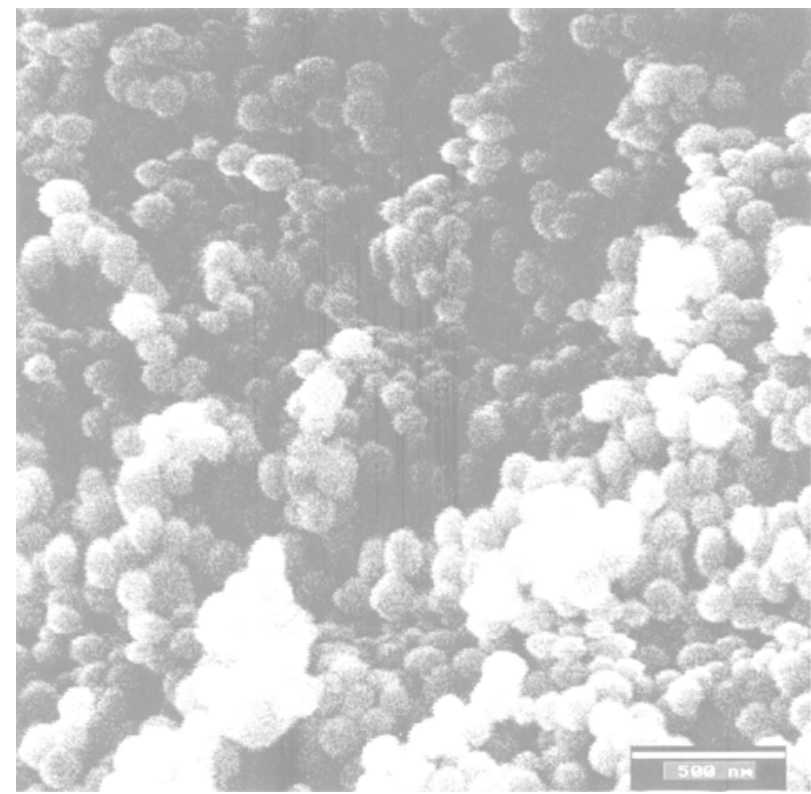

Figure 19: SEM image of the SINT-37, 2 wt.\% functionalized nano- $\mathrm{SiO}_{2}$ (diameter $\left.=90 \mathrm{~nm}\right)$.

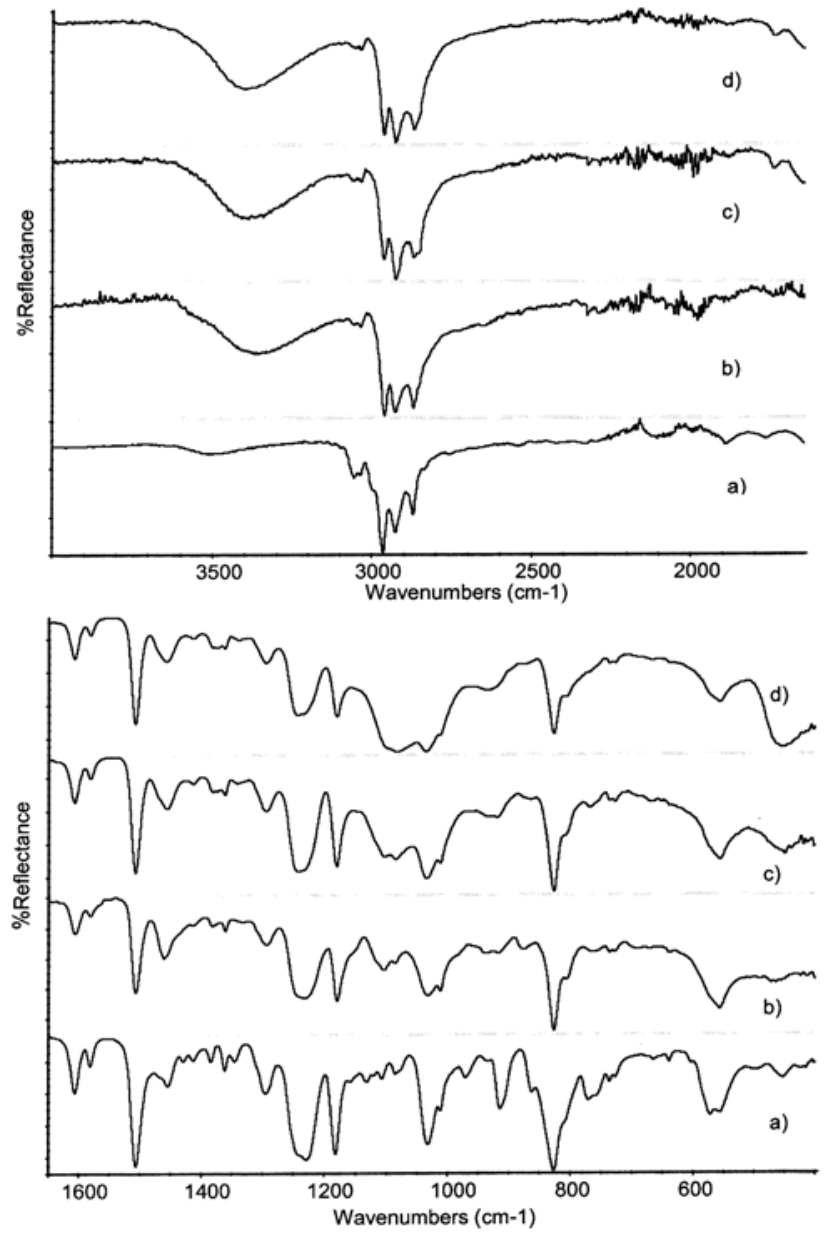

Figure 20: FTIR: epoxy (a) prepolymer, (b) /D-230, (c) /5 and (d) /50 wt.\%-mod. nanosilica/D-230.

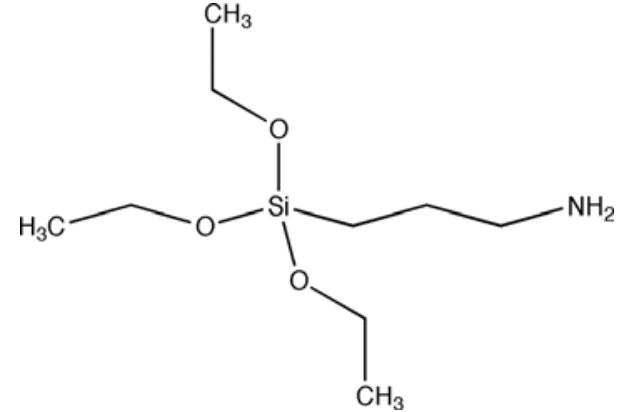

Figure 21: Molecular structure of 3-aminopropyltriethoxysilane (APTES).

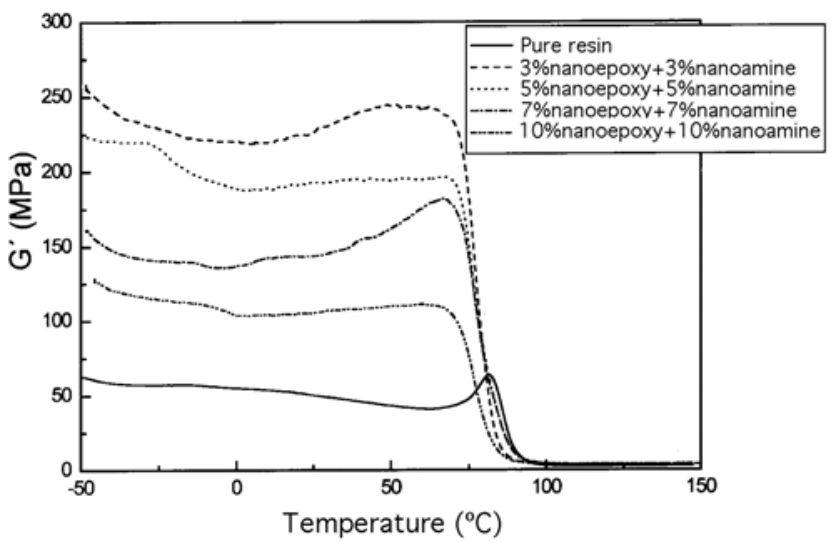

Figure 22: Storage modulus in shear $G^{\prime}$ for the samples strengthened with nano-SiO ${ }_{2} /$ epoxy + /amine.

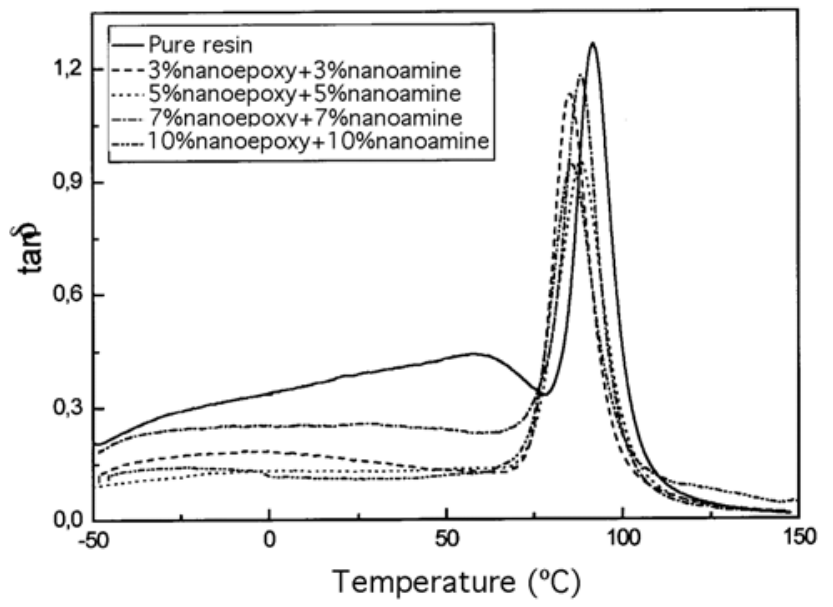

Figure 23: Loss factor in shear $\tan \delta$ for samples reinforced with nano-SiO ${ }_{2}$-epoxy $+\mathrm{SiO}_{2}$-amine.

\section{CONCLUSION}

The present results and discussion allow the following conclusions.

1. Composites consisting of epoxy cross-linked with silica nanospheres were synthesised, which present improved thermal and may be expected 
to show better high-temperature mechanical properties than the product cured in the absence of nanosilica.

2. Currently we are tuning the synthetic methods to obtain modified nanospheres in much greater quantities than those at present, in order to facilitate the measurement of the tensile strength.

3. Work is in progress on improving the retention of the structures of epoxy-modified nanosilica, improving their mechanical behaviour at high temperatures, as the loss of weight can cause effects on network defects because of the loss of cross-links by unit of volume.

4. Nanosilica particle incorporation into epoxy improved mechanical properties for low concentration. Thermal characteristic behaviour of all samples did not only improve but also exhibited constant thermal stability, in comparison to neat epoxy. Our method improved epoxy thermal and mechanical properties and is a good starting point for developing materials.

5. The glass-transition temperature decays with increasing nanosilica content, which attributes to the increase in the mobility of polymer chains.

6. A low weight percentage of filler results in matrix reinforcement. Additionally, the properties no longer improve with further filler content. The corresponding interpretation is that a rise in filler proportion causes an increase in viscosity, which produces a poorer filler dispersion in the matrix.

\section{ACKNOWLEDGEMENT}

The authors want to dedicate this manuscript to Prof. Dr. Agustín Campos, who was greatly interested in this research and would have loved to see its conclusion.

\section{REFERENCES}

[1] Krishnan AV, Stathis P, Permuth SF, Tokes L, Feldman D. Bisphenol-A: An estrogenic substance is released from polycarbonate flasks during autoclaving. Endocrinology 1993; 132: 2279-86. http://dx.doi.org/10.1210/en.132.6.2279

[2] Deligio T. The BPA debate from two perspectives. Mod Plast Worldwide 2010; 87(6): 12-8.

[3] Stillman RJ. In utero exposure to diethylstilbestrol: Adverse effects on the reproductive tract and reproductive performance of male and female offspring. Am J Obstet Gynecol 1982; 142: 905-21.
Schrager S, Potter BE. Diethylstilbestrol exposure. Am Fam Physician 2004; 69: 2395-400.

[5] Olsen CM, Meussen-Elholm ETM, Samuelsen M, Holme JA, Hongslo JK. Effects of the environmental oestrogens bisphenol $\mathrm{A}$, tetrachlorobisphenol $\mathrm{A}$, tetrabromobisphenol $\mathrm{A}$, 4-hydroxybiphenyl and 4,4'-dihydroxybiphenyl on oestrogen receptor binding, cell proliferation and regulation of oestrogen sensitive proteins in the human breast cancer cell line MCF-7. Pharmacol Toxicol 2003; 92: 180-8. http://dx.doi.org/10.1034/j.1600-0773.2003.920408.x

[6] Birnbaum LS, Staskal DF. Brominated flame retardants: Cause for concern? Environ Health Perspect 2004; 112: 917.

http://dx.doi.org/10.1289/ehp.6559

[7] Song W, Li Z, Ding F. Determination of bisphenol A in effluent water of analogue MBR wastewater treatment system using high-performance liquid chromatography. Res J Chem Environ 2011; 15(2): 8-12.

[8] Herrero-Hernández E, Carabias-Martínez R, RodríguezGonzalo E. Behavior of phenols and phenoxyacids on a bisphenol-A imprinted polymer. Application for selective solid-phase extraction from water and urine samples. Int $\mathrm{J}$ Mol Sci 2011; 12: 3322-39.

http://dx.doi.org/10.3390/ijms12053322

[9] Singh S, Li SSL. Epigenetic effects of environmental chemicals bisphenol A and phthalates. Int J Mol Sci 2012; 13: 10143-53.

http://dx.doi.org/10.3390/ijms130810143

[10] Sourour S, Kamal MR. Differential scanning calorimetry of epoxy cure: Isothermal cure kinetics. Thermochim Acta 1976; 14: $41-59$. http://dx.doi.org/10.1016/0040-6031(76)80056-1

[11] Núñez L, Fraga F, Fraga L, Castro A. Kinetic and thermodynamic studies of an epoxy system diglycidyl ether of bisphenol-A/1,2 diamine cyclohexane. J Appl Polym Sci 1997; 63: 635-41.

http://dx.doi.org/10.1002/(SICI)10974628(19970131)63:5<635::AID-APP11>3.0.CO;2-T

[12] Fraga $F$, Penas $M$, Castro $C$, Rodríguez-Núñez E, MartínezAgeitos JM. Cure kinetics of a diglycidyl ether of bisphenol $A$ epoxy network $(n=0)$ with isophorone diamine. J Appl Polym Sci 2007; 106: 4169-73 http://dx.doi.org/10.1002/app.26989

[13] Ghosh NN, Kiskan B, Yagci Y. Polybenzoxazines-New high performance thermosetting resins: Synthesis and properties. Prog Polym Sci 2007; 32: 1344-91. http://dx.doi.org/10.1016/j.progpolymsci.2007.07.002

[14] Takeichi T, Saito Y, Agag T, Muto H, Kawauchi T. Highperformance polymer alloys of polybenzoxazine and bismaleimide. Polymer 2008; 49: 1173-9. http://dx.doi.org/10.1016/j.polymer.2008.01.041

[15] Sharifi S. Dielectric spectroscopy of diglycidyl ether of bisphenol-A at glass transition temperature. Nat Sci 2012; 4 136-41.

[16] Wang Q, Chen G. Effect of nanofillers on the dielectric properties of epoxy nanocomposites. Adv Mater Res 2012; 1 93-107. http://dx.doi.org/10.12989/amr.2012.1.1.093

[17] Zhao C, Zhang G, Zhao L. Effect of curing agent and temperature on the rheological behavior of epoxy resin systems. Molecules 2012; 17: 8587-94. http://dx.doi.org/10.3390/molecules 17078587

[18] Prolongo SG, Gude MR, Urena A. Adhesive strength and toughness improvement of epoxy resin modified with polystyrene-b-polybutadiene-b-poly (methyl methacrylate) block copolymer. J Mater Sci Eng 2012; 1: 109-1-5.

[19] Akande IS, Hassan O, Adeshakin A. Gas chromatographymass spectrophotometry evaluation of the concentration of bisphenol-A (BPA) in five selected canned food products 
consumed in Lagos Area, Nigeria. Br J Appl Sci Technol 2014; 4: 187-97.

[20] Tarko L, Putz MV, Ionascu C, Putz AM. QSTR studies regarding the ECOSAR toxicity of benzene-carboxylic acids' esters to fathead minnow fish (Pimephales promelas). Curr Comput Aided Drug Des, submitted for publication.

[21] Piscitelli F, Lavorgna M, Buonocore GG, Verdolotti L, Galy J, Mascia L. Plasticizing and reinforcing features of siloxane domains in amine-cured epoxy/silica hybrids. Macromol Mater Eng 2013; 298: 896-909.

http://dx.doi.org/10.1002/mame.201200222

[22] Verdolotti L, Lavorgna M, Oliviero M, Sorrentino A, lozzino V, Buonocore G, lannace S. Functional zein-siloxane biohybrids. ACS Sust Chem Eng, in press.

[23] Torrens F, Soria V, Monzó IS, Abad C, Campos A. Treatment of poly(styrene-co-methacrylic acid)/poly(4-vinylpyridine) blends in solution under liquid-liquid phase-separation conditions. A new method for phase-separation data attainment from viscosity measurements. J Appl Polym Sci 2006; 102: 5039-49. http://dx.doi.org/10.1002/app.25082

[24] Torrens F, Soria V, Codoñer A, Abad C, Campos A. Compatibility between polystyrene copolymers and polymers in solution via hydrogen bonding. Eur Polym J 2006; 42: 2807-23.

http://dx.doi.org/10.1016/j.eurpolymj.2006.04.020

[25] Torrens F, Monzó IS, Gómez-Clarí CM, Abad C, Campos A. Study and comparison of interaction parameters and phase behaviour of epoxy/polystyrene and epoxies copolymer polystyrene-b-poly(methyl methacrylate) blends. Polym Compos 2008; 29: 1337-45.

http://dx.doi.org/10.1002/pc.20518

[26] Torrens F, Castellano G. Determination of binodal curves in ternary polymer systems: Co-/polymers compatibility. In: Kumar SA, Thiagarajan S, Wang SF, editors. New developments in polymer composites research. New York: Nova, in press.

[27] Torrens F, Gómez CM, León LM, Abad C, Campos A. Modelling studies of the phase behaviour of monomer/polymer/disk composites. Macromol Theory Simul 2008; 17: 325-40.

http://dx.doi.org/10.1002/mats.200800013

[28] Torrens F, Gómez CM, Monzó IS, Abad C, Campos A. Modelling Monomer/Disc Composites Phase Behaviour. Macromol Symp 2012; 311: 49-56. http://dx.doi.org/10.1002/masy.201000108

[29] Torrens F, Castellano G. Experimental studies for modelling the phase behaviour of monomer/polymer/disc composites. Macromol Symp 2010; 296: 557-65.

http://dx.doi.org/10.1002/masy.201051073

[30] Torrens F, Monzó IS, Gómez-Clarí CM, Abad C, Campos A. Study and comparison of interaction parameters and phase behaviour of epoxy/polystyrene and epoxies copolymer polystyrene-b-poly(methyl methacrylate) blends. Polym Compos 2008; 29: 1337-45.

http://dx.doi.org/10.1002/pc.20518

[31] Torrens F, Solar L, Puchol V, Latorre J, Abad C, Campos A. Incorporation of silica nanospherical particles into epoxy- amine cross-linked materials. Polym Polym Compos 2008; 16: 139-52.

[32] Torrens F, Castellano G. Incorporation of silica nanospheres into epoxy-amine materials: Polymer nanocomposites. In: Lechkov M, Prandzheva S, editors. Encyclopedia of polymer composites: Properties, performance and applications. Polymer Science and Technology No. 5. New York: Nova 2010; p. 823-44.

[33] Torrens-Zaragozá F. Polymer bisphenol-A, the incorporation of silica nanospheres into epoxy-amine materials and polymer nanocomposites. Nereis 2011; (3): 17-23.

[34] León LM, Laza M, Torrens F, Puchol V, Abad C, Campos A. Incorporation of silica nanospherical particles in epoxyamine cross-linked materials II. Dynamic mechanical measurements of epoxy matrix-silica nanocomposites. Polym Polym Compos 2009; 17: 457-65.

[35] León LM, Laza M, Puchol V, Torrens F, Abad C, Campos A. Dynamic mechanical measurements of epoxy matrix-silica nanocomposites II. Polym Polym Compos 2009; 17: 313-24.

[36] Fiege H, Voges HW, Hamamoto T, Umemura S, Iwata T, Miki H, Fujita Y, Buysch HJ, Garbe D, Paulus W. Phenol derivatives. In: Ullmann's encyclopedia of industrial chemistry. Weinheim (Ger.): Wiley-VCH 2002.

[37] Bateman C. Get your coat. Hydrocarbon Eng 2012; 17(3): 74-80.

[38] Kharasch MS, Kleiman M. Synthesis of polyenes. III. A new synthesis of diethylstilbestrol. J Am Chem Soc 1943; 65: 115. http://dx.doi.org/10.1021/ja01241a004

[39] Barton JM. The application of differential scanning calorimetry (DSC) to the study of epoxy resin curing reactions. Adv Polym Sci 1985; 72: 112-54.

http://dx.doi.org/10.1007/3-540-15546-5 5

[40] Rozenberg BA. Kinetics, thermodynamics and mechanism of reactions of epoxy oligomers with amines. Adv Polym Sci 1986; 75: 113-65. http://dx.doi.org/10.1007/BFb0017916

[41] Riccardi CC, Adabbo HE, Williams RJJ. Curing reaction of epoxy resins with diamines. J Appl Polym Sci 1984; 29: 2481-92. http://dx.doi.org/10.1002/app.1984.070290805

[42] Kim DH, Kim SC. Vitrification effect on the curing reaction of epoxy resin. Polym Bull (Berlin) 1987; 18: 533-9.

[43] Laza JM, Julian CA, Larrauri E, Rodriguez M, Leon LM. Thermal scanning rheometer analysis of curing kinetic of an epoxy resin: 2. An amine as curing agent. Polymer 1998; 40: 35-45.

http://dx.doi.org/10.1016/S0032-3861(98)00217-1

[44] Carrozzino S, Levita G, Rolla P, Tombari E. Calorimetric and microwave dielectric monitoring of epoxy resin cure. Polym Eng Sci 1990; 30: 366-73. http://dx.doi.org/10.1002/pen.760300608

[45] Vyazorkin S, Shinazzuoli N. Mechanism and kinetics of epoxy-amine cure studied by differential scanning calorimetry. Macromolecules 1996; 29: 1867-73. http://dx.doi.org/10.1021/ma951162w 